\title{
Redescription of Limnoithona tetraspina Zhang et Li, 1976 (Copepoda, Cyclopoida) with a discussion of character states shared with the Oithonidae and older cyclopoids
}

\author{
Bernardo Barroso do Abiahy ${ }^{1}$, Carlos Eduardo Falavigna da \\ Rocha $^{2}$, Frank D. Ferrari ${ }^{3}$
}

\author{
${ }^{1}$ Avenida Manuel Hipolito do Rego 1270/ap. 09, 11.600-000 Sao Sebastiao, SP, Brasil \\ ${ }^{2}$ Universidade de São Paulo, Instituto de Biociências, Departamento de Zoologia, Rua do Matão, \\ travessa 14, No. 321, 05508-900 São Paulo, Brazil \\ ${ }^{3}$ Department of Invertebrate Zoology, MRC-534, National Museum of Natural History, Smithso- \\ nian Institution, 4210 Silver Hill Rd., Suitland, MD 20746 U.S.A.
}

\begin{abstract}
Limnoithona tetraspina Zhang et Li, 1976 is redescribed, and the morphology of the cephalosome, rostral area, oral appendages, legs 1-6 and urosome of adult males and females is illustrated. Morphological features separating L. tetraspina from its only congener, L. sinensis, include: a more pronounced rostrum; 1 seta more on the proximal lobe of the basis of the maxillule; 1 seta more on the endopod of the maxillule; middle endopodal segment of swimming legs 2-4 with 1 seta more; proximal and distal seta of the middle endopodal segment of swimming leg 4 with a flange; exopod of leg 5 with a proximal lateral seta; male cephalosome ventrally with pores with cilia. A rounded projection between labrum and rostrum is a shared derived state for both species of Limnoithona. Derived morphological features of the remaining species of Oithonidae, which are not shared with L. tetraspina and L. sinensis, include: elongation of the mandibular basis; fusion of the proximal endopodal segment of the mandible of females to the basis; 2 setae of the fused proximal endopodal segment of the mandible extend ventral to labrum; 3 setae on the proximal complex of three endopodal segments of the maxilliped. The two species of Limnoithona do not belong to the Oithonidae. They appear to be closely related to species of Cyclopettidae, but at this time it would not be meaningful to assign them to a known family of the Cyclopoida or to propose a new family for them. The following morphological attributes which are shared with different related cyclopoids also are discussed: shape of female cephalosome; pores with cilia on male cephalosome; setation of basis and proximal segment of the endopod of the mandible; brush-like setae on the exopod of the mandible; setation of the maxillule including brush-like seta on the exopod; hyaline flange on setae of the endopod of swimming leg 4; lateral location of copulatory pores and leg 6 of females, and of leg 5 in both genders; configuration of leg 5 .
\end{abstract}

KEYWORDS: Copepoda, Cyclopoida, Limnoithona, taxonomy, brackish water, zooplankton. 


\title{
Переописание Limnoithona tetraspina Zhang et Li, 1976 (Copepoda, Cyclopoida) с обсуждением эволюционного значения признаков общих с Oithonidae и другими более древними циклопоидами
}

\author{
Б.Б. Абиахиㅜ, К.Э.Ф. Роча², Ф.Д. Феррари
}

\begin{abstract}
${ }^{1}$ Avenida Manuel Hipolito do Rego 1270/ap. 09, 11.600-000 Sao Sebastiao, SP, Brasil
${ }^{2}$ Universidade de São Paulo, Instituto de Biociências, Departamento de Zoologia Rua do Matão, travessa 14, No. 321, 05508-900 São Paulo, Brazil

${ }^{3}$ Department of Invertebrate Zoology, MRC-534, National Museum of Natural History, Smithsonian Institution, 4210 Silver Hill Rd., Suitland, MD 20746 U.S.A.
\end{abstract}

РЕЗЮМЕ: Переописание Limnoithona tetraspina Zhang et Li, 1976 сопровождается иллюстрациями цефалосомы, ростральной поверхности, околоротовых конечностей, 1-6-й пар плавательных ног и уросомы половозрелых самцов и самок этого вида. L. tetraspina отличается от второго представителя рода L. sinensis следующими морфологическими особенностями: рострум более развит; на одну щетинку больше на проксимальной лопасти базиса и эндоподита максиллул; средний членик эндоподита 2-4-й пар плавательных ног несет на одну щетинку больше; проксимальная и дистальная щетинки среднего членика эндоподита 4-й плавательной ноги имеют уплощенный край; проксимальная часть экзоподита 5-й ноги с латеральной щетинкой; вентральная сторона цефалосомы самца снабжена порами с сенсиллами. Округлый выступ между губой и рострумом - уникальный признак, общий для двух видов Limnoithona. Уникальные признаки других видов Oithonidae, отсутствующие у L. tetraspina и L. sinensis: удлиненный базис мандибул; слитие базиса с проксимальным члеником эндоподита мандибулы самки; две щетинки проксимального членика эндоподита мандибулы вытянуты вниз к лабруму; три щетинки на комплексе из трех проксимальных члеников эндоподита максиллипеды. Оба вида Limnoithona не принадлежат семейству Oithonidae. Они, вероятно, наиболее близки к представителям семейства Cyclopettidae, но, в настоящее время, перенос двух видов в известное семейство Cyclopoida, равно как и выделение нового семейства, являются преждевременными. Обсуждаются морфологические признаки циклопоид близких к этим двум видам: форма цефалосомы самки; поры с сенсиллами на цефалосоме самца; вооружение щетинками базиса и проксимального членика эндоподита мандибул; кисточковидная щетинка на экзоподите мандибул; вооружение щетинками максиллулы, в том числе кисточковидной щетинкой ее экзоподита; гиалиновый край щетинок эндоподита 4-й плавательной ноги; латеральное положение копуляторных пор и 6-й ноги самки, а также 5-й ноги у обоих полов; форма 5-й ноги.

КЛЮЧЕВЫЕ СЛОВА: Copepoda, Сyclopoida, Limnoithona, таксономия, солоноватоводные водоемы, зоопланктон. 


\section{Introduction}

Limnoithona tetraspina Zhang et Li, 1976 was described from specimens collected in April, 1974, in brackish waters of the Yangtze river, around Tsungming island, Xangai, China. Characters proposed to separate this species from its only congener $L$. sinensis were: the obtuse and ventrally projected rostrum; endopod 2 of swimming legs 2-3 with 2 medial setae; free segment of leg 5 with 2 lateral marginal spines. Aspects illustrated were the body in dorsal view, female and male legs 1 to 5, female rostral area and the male antennule. The inclusion of Limnoithona within the Oithonidae as a subgenus of Oithona was proposed by Burckhardt (1913) based on the description of specimens of L. sinensis collected in China (Sutschau Canal, Wangpu and Yangtze rivers). Kiefer (1928) created the subfamily Limnoithoninae to which L. sinensis was placed. Ferrari and Orsi (1984) showed in detail much of the morphology of $L$. sinensis, which remains the only other species of the genus.

Here we provide a redescription of $L$. tetraspina. We note a series of its character states which are shared with $L$. sinensis, and that diverge from the general morphology of the remaining genera of Oithonidae, Oithona, Dioithona and Paroithona. We also discuss characters which may help resolve the relationships of these two species of Limnoithona with other cyclopoids.

\section{Material and Methods}

Material examined: 3 females and 4 males collected in the Sacramento/San Joaquin estuary, California, USA. Date of sampling and name of collector unknown. Specimens were provided by the California Department of Fish and Game.

Specimens preserved in ethanol $90 \%$ with $10 \%$ water were mounted in lactic acid $80 \%$ with $20 \%$ water, and examined under a Laborlux light microscope. Objective magnifications of $25 \mathrm{x}, 40 \mathrm{x}$ and $100 \mathrm{x}$ were used in conjunction with $10 x$ oculars. A camera lucida $(1.25 \mathrm{x})$ was used to make the drawings. Type material was not examined. Specimens examined reside in personal collections of CEFdR and FDF.

A pediger is a thoracic somite bearing a swimming leg. In general, descriptive terms follow (Ferrari 1995). Interpretations of homologies of the maxillule follow Boxshall (1985), of the maxilla follow Ferrari and Ivanenko (2005), of the maxilliped follow Ferrari and Ivanenko (2001); the protopod of these three limbs has a coxa with one setiferous endite.

Abbreviations used in descriptive section:

A1 - antennule; A2 - antenna; $\mathrm{Cx}$ coxa; B — basis; Enp - endopod; Enp1-Enp3 - first to third segments of endopod; Exp exopod; Exp1-Exp3 - first to third segments of exopod; Md - mandible; Mx1 — maxillule; Mx2 - maxilla; Mxp - maxilliped; P1-P4swimming legs 1 to 4; P5-P6 - legs 5-6.

Сокращения, используемые в описании: А1 - антеннула; А2 - антенна; Сх кокса; В - базис; Enp — эндоподит; Enp1Enp3 - первый-третий членики эндоподита; Exp - экзоподит; Exp1-Exp3 - первыйтретий членики экзоподита; Md мандибула; Mх1 - максиллула; Мх2 максилла; Мхр - максиллипеда; Р1-P4 1-4 плавательные ноги; Р5-Р6 - 5-6 ноги.

\section{Redescription of Limnoithona tet- raspina Zhang et Li, 1976}

Female. Body length excluding caudal setae: $0.55 \mathrm{~mm}$; prosome: urosome 1.42:1. Major width of body at posterior limit of cephalosome. Cephalosome (Fig. 1A) partially fused to pediger 1; anterior border of pediger 1 indicated by thin, lateral arthrodial membrane absent dorsally. Cephalosome (Fig. 1B) with short lateral triangular extension at each posterior corner. Rostrum (Fig. 1C) relative short and projecting ventrally, slightly obtuse in lateral view and rounded in ventral view; area between rostrum and labrum with rounded projection in lateral view. Pedigers 1-2 about same width in lateral view; pedigers 3-4 gradually narrowing, with rounded corners (Figs 1 A, B). Genital double somite swollen anteriorly (Fig. 1A). Anal somite (Fig. 1A) 1.25 times longer than wide and as long as lengths of 2 preceding somites combined; anal flap simple, arclike. 


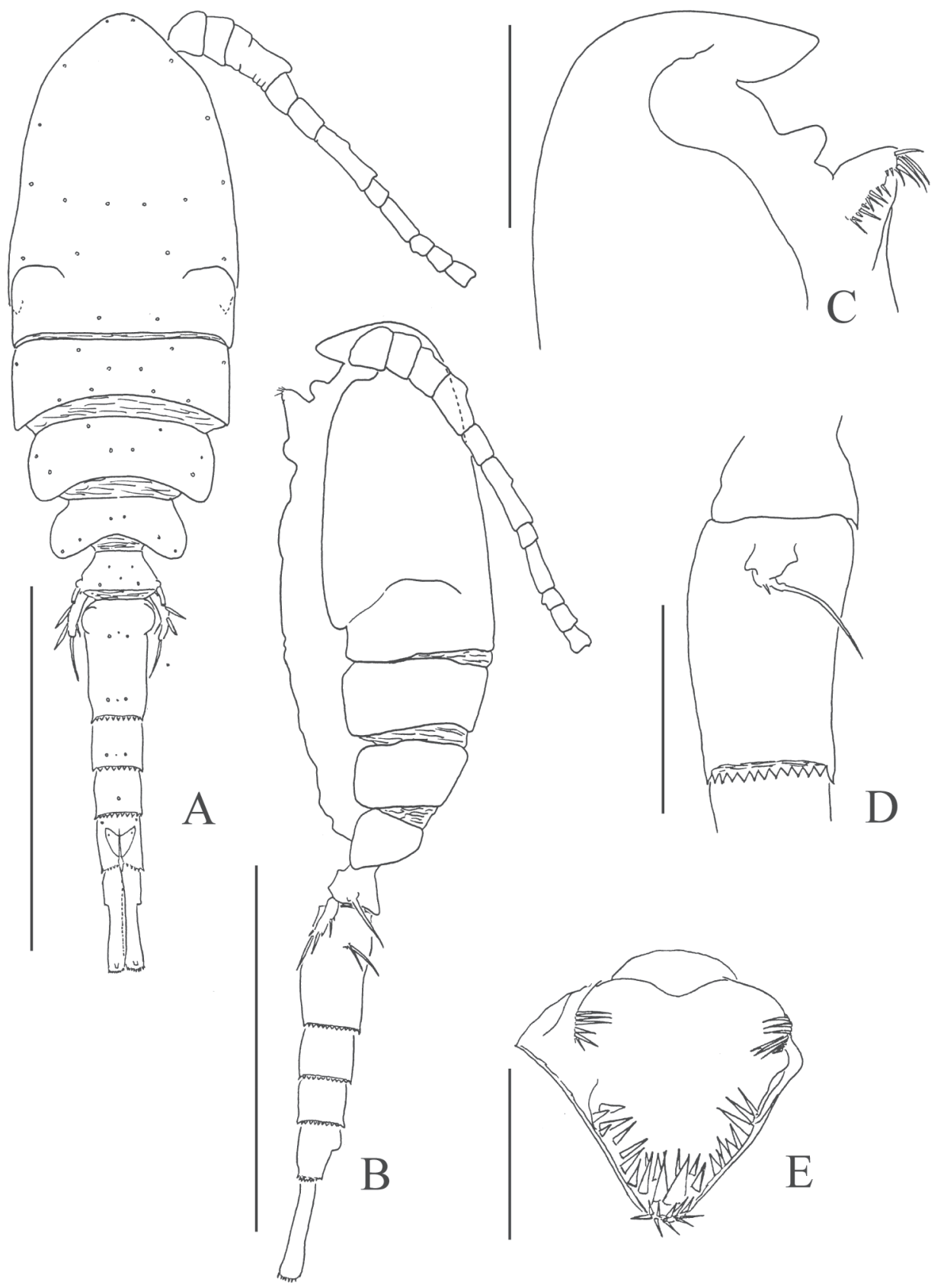

Fig. 1. Limnoithona tetraspina Zhang et Li, 1976. Female.

A - habitus, dorsal (left antennule not present); B - habitus, left lateral (oral appendages and swimming legs not present); C - anterior region of cephalosome, right lateral; D — genital complex, left lateral; E — labrum, ventral. Scale bars: A, B $-0.20 \mathrm{~mm}$; C, D $-0.50 \mathrm{~mm}$; E $-0.025 \mathrm{~mm}$.

Рис. 1. Limnoithona tetraspina Zhang et Li, 1976. Самка:

A - общий вид со спины (левая антенна не показана); В - общий вид слева (околоротовые конечности и плавательные ноги не показаны); C — передняя часть цефалосомы, вид справа; D - генитальный комплекс, вид слева; Е - лабрум, вид снизу. Масштаб: А, В - 0,20 мм; C, D - 0,50 мм; Е - 0,025 мм. 


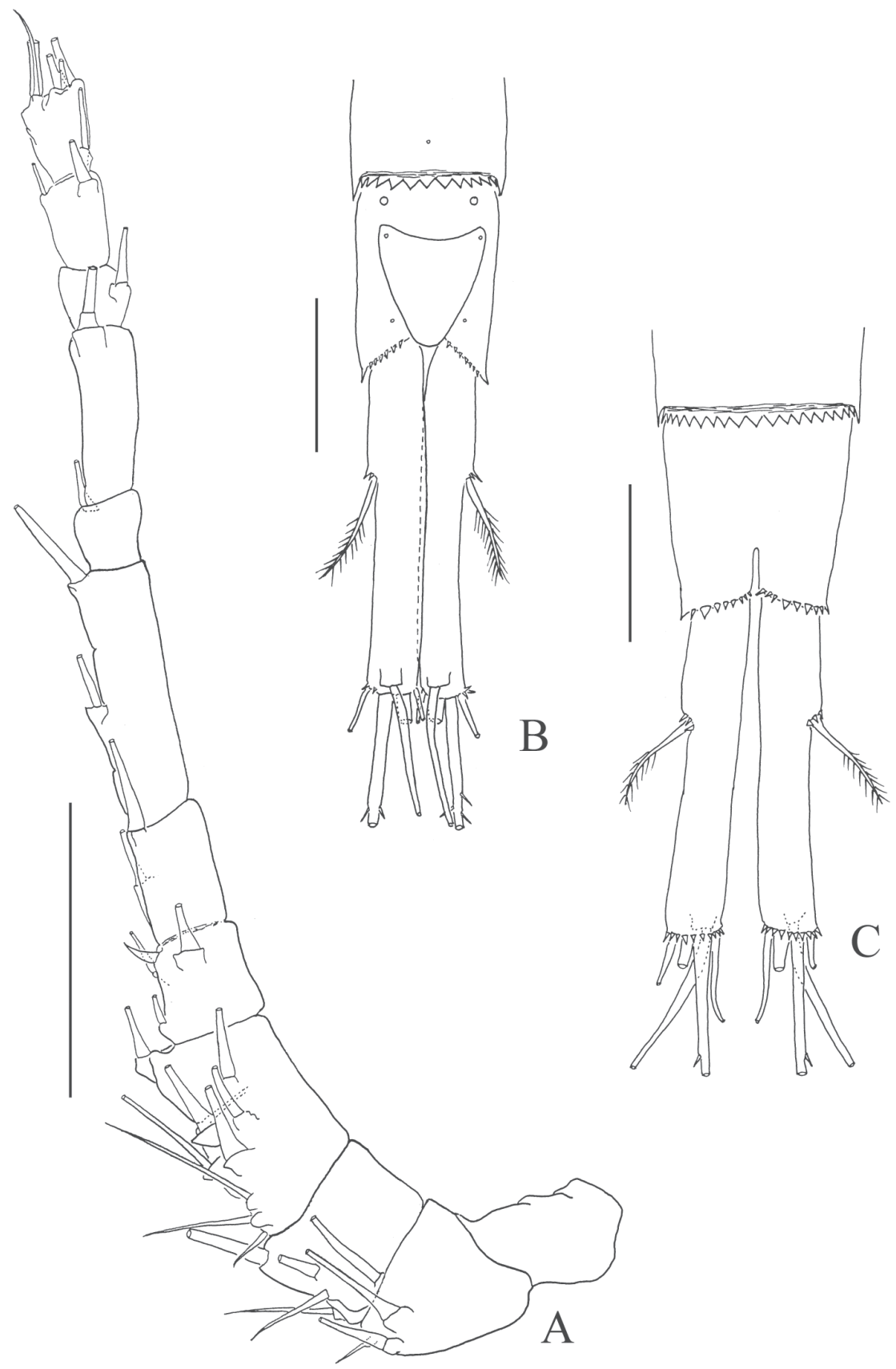

Fig. 2. Limnoithona tetraspina Zhang et Li, 1976. Female.

$\mathrm{A}$ - antennule; B - anal segment and caudal ramus, dorsal; $\mathrm{C}$ - anal segment and caudal ramus, ventral. Scale bars: $\mathrm{A}-0.025 \mathrm{~mm}$; B, C $-0.50 \mathrm{~mm}$.

Рис. 2. Limnoithona tetraspina Zhang et Li, 1976. Самка:

А - антеннула; В - анальный сегмент и каудальная ветвь, вид со спины; C - анальный сегмент и каудальная ветвь, вид снизу. Масштаб: А $-0,025$ мм; В, C-0,50 мм. 
A1 (Fig. 2A) with 11 segments, reaching no further than posterior border of pediger 1 ; aesthetascs absent; setal armament of segments, proximally to distally: $3,5,9,3+1$ spine, $2,2,1,1,1,2$, $5+1$ short, thin seta.

Labrum (Fig. 1C, E) represented by triangular lobe in ventral view with 16-20 articulated spinules.

A2 (Fig. 4A) basis with 1 distomedial seta. Enp 3 -segmented. Enp1 bearing 1 medial seta at midlength. Enp2 with 2 short medial setae and 3 long distomedial setae; Enp3 with 7 setae at tip plus proximodistal muscles internally. Exopod absent.

$\mathrm{Md}$ comprising gnathobase (not figured) and palp. Mandibular palp (Fig. 3B) consisting of basis, 2-segmented Enp, and 4-segmented Exp. Basis with 1 medial seta. Enp1 with 3 plumose setae. Enp2 with 5 setae. Exp1-3 each with 1 seta. Exp4 with 2 setae, lateral terminal seta short with brush-like tip.

Mx1 (Fig. 3A) with praecoxal endite welldeveloped, bearing 10 setae. Endite of coxa with plumose seta. Coxal epipodite carrying 1 short and 1 long seta. Basis with both endites similar in shape and size; proximal endite with 3 setae, middle seta robust and spinulate; distal endite with 2 setae. Enp 1-segmented with 5 setae. Exp 1segmented with 4 setae; medial seta short with brush-like tip.

Mx2 (Fig. 4B) consisting of syncoxa with 2 endites, a praecoxal endite with 4 setae and a coxal endite with 1 seta. Basis with 2 endites, each with 3 setae. Enp 4-segmented; Enp1 expanded into claw with short seta at base, and with 1 long seta medially and a shorter seta posteriorly. Enp2 with 4 setae. Enp3 with 2 setae. Enp4 with 4 setae.

Mxp (Fig. 4C) with praecoxa of 2 lobes, proximal with 1 seta and distal with 3 setae. Coxal lobe with 2 setae. Basis elongate with 2 setae and medial denticles. Endopod 2-segmented. Enp1 with 1 seta. Enp2 with 2 long and 1 short setae.

P1-P4 (Fig. 5A-D) armament as indicated in Table 1. face.

Basis of all legs with tegumental pore on anterior

Enp2 of P4 proximal and distal medial setae curved and with hyaline membrane along the distal section.

P5 basis fused to pediger 5; lateral seta of basis originating on protuberance of pediger. Exp 1-segmented with 2 lateral spines, 1 long apical seta, and 1 short, medial seta (Fig. 3C).

P6 a bud laterally with 1 long seta and 1 spinule (Fig. 1D).

Caudal ramus (Fig. 2B, C) 5.5 times longer than wide, about twice length of anal somite with 1 dorsal, 1 lateral and 4 terminal setae.

Male. Body length excluding caudal setae 0.38 $\mathrm{mm}$; prosome: urosome 1.2:1. Major width of body at posterior limit of cephalosome (Fig. 6A, B). Pediger 1 partially fused to cephalosome dorsally (Fig. 6A), as in female. Cephalosome with a short, lateral triangular extension at each posterior corner; pores with cilia along ventral and posterior margins of cephalosome and extension; pores without cilia on lateral face of cephalosome (Figs 6B). Urosome 6segmented (Figs 6A, B); genital somite swollen anteriorly and slightly more developed than subsequent segments. Caudal ramus (Figs 6C, D) about 4.5 times longer than wide.

A1 with 17 segments and armed as shown in Fig. 7B; proximal geniculation between segments 10 and 11; distal geniculation well marked between segments 15 and 16; each of the 4 segments preceding

Table 1. P1-P4 setae and lateral marginal spine armament (Roman numerals indicate apical and lateral marginal spines and Arabic numerals indicate medial and lateral setae).

Таблица 1. Вооружение щетинками и латеральными краевыми шипами 1-4 плавательных ног (римские цифры обозначают апикальные и латеральные краевые шипы, арабские цифры медиальные и латеральные щетинки).

\begin{tabular}{|l|c|c|c|c|c|c|c|c|}
\hline & Cx & B & B & Exp2 & Exp3 & Enp1 & Enp2 & Enp3 \\
\hline P1 & $0-1$ & $1-\mathrm{I}$ & $1-\mathrm{I}$ & I-1 & III-I+1-3 & $0-1$ & $0-1$ & $1-2-3$ \\
\hline P2 & $0-1$ & $1-0$ & $1-0$ & I-1 & III-I+1-4 & $0-1$ & $0-2$ & $1-2-3$ \\
\hline P3 & $0-1$ & $1-0$ & $1-0$ & I-1 & III-I+1-4 & $0-1$ & $0-2$ & $1-2-3$ \\
\hline P4 & $0-1$ & $1-0$ & $1-0$ & I-1 & III-I+1-4 & $0-1$ & $0-2$ & $1-2-2$ \\
\hline
\end{tabular}




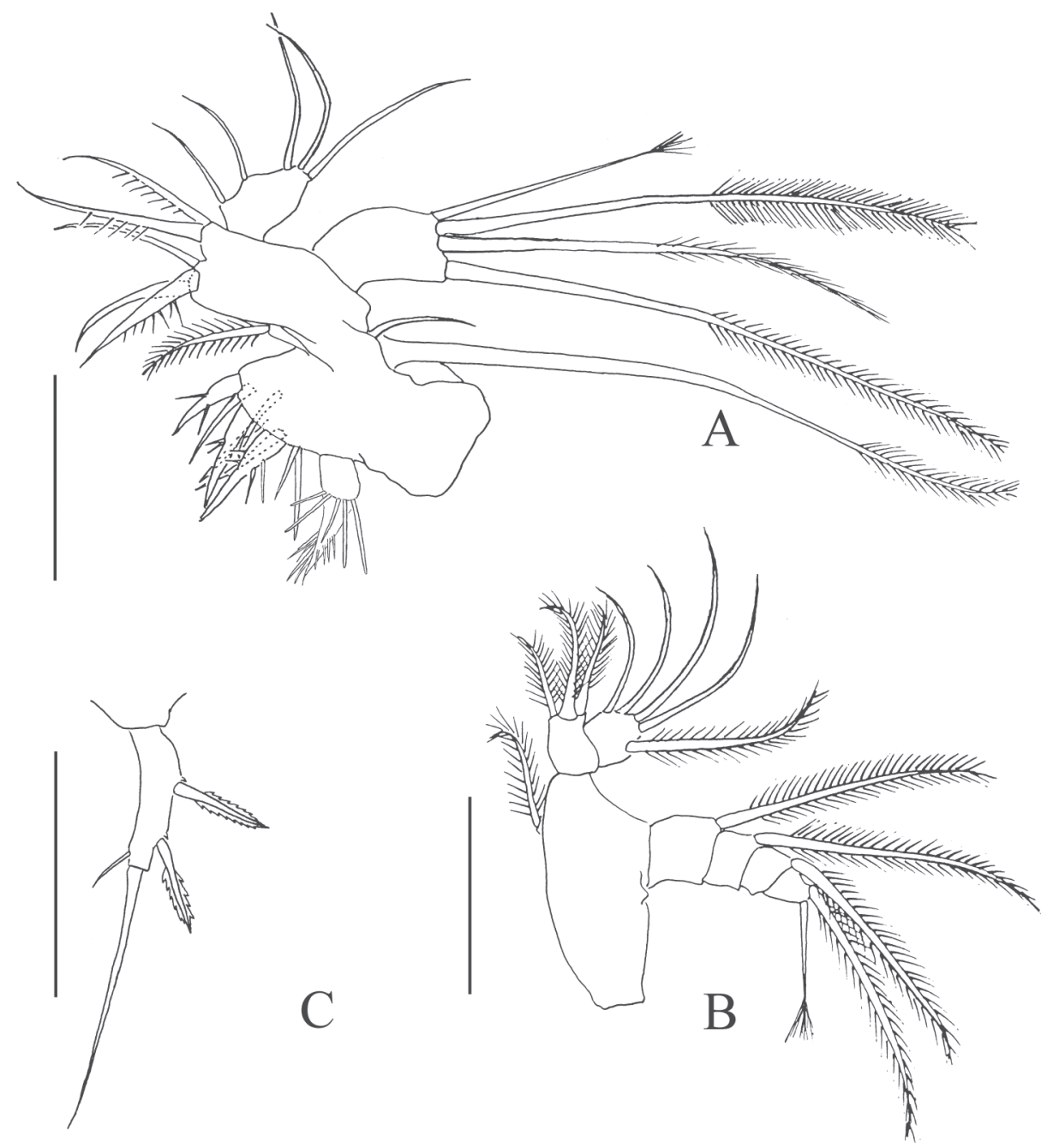

Fig. 3. Limnoithona tetraspina Zhang et Li, 1976. Female.

A - maxillule; B - mandibular palp; C - exopod of leg 5. Scale bars: A, B $-0.025 \mathrm{~mm}$; C $-0.05 \mathrm{~mm}$.

Рис. 3. Limnoithona tetraspina Zhang et Li, 1976. Самка:

A - максиллула; В - пальпа мандибул; С - экзоподит 5-й ноги. Масштаб: А, В $-0,025$ мм; C - 0,05 мм.

the distal geniculation with 1 spiniform seta; terminal segment without aesthetasc.

A2 (Fig. 9C) with distinct, unarmed coxa. Basis without seta; poorly defined articulation between basis and Enp1. Enp1-Enp3 armed as in female.

Md (Fig. 8A), Mx1 (Fig. 8B), Mx2 (Fig. 8C), Mxp (Fig. 8D), P1-P4 (Figs. 10A-D) and P5 (Fig. $9 \mathrm{~A}, \mathrm{~B})$ similar to female.

P6 a ventrolateral, bud-like flap with 1 long and 1 short seta (Fig. 9A, B).

\section{Comments}

A re-examination of specimens of $L$. sinensis from the Sacramento-San Joaquin River confirms (personal collection of FDF): complete arthrodial membrane between the basis and endopod of the mandible; 2 setae on the proximal lobe of the basis of the maxillule and 4 setae 


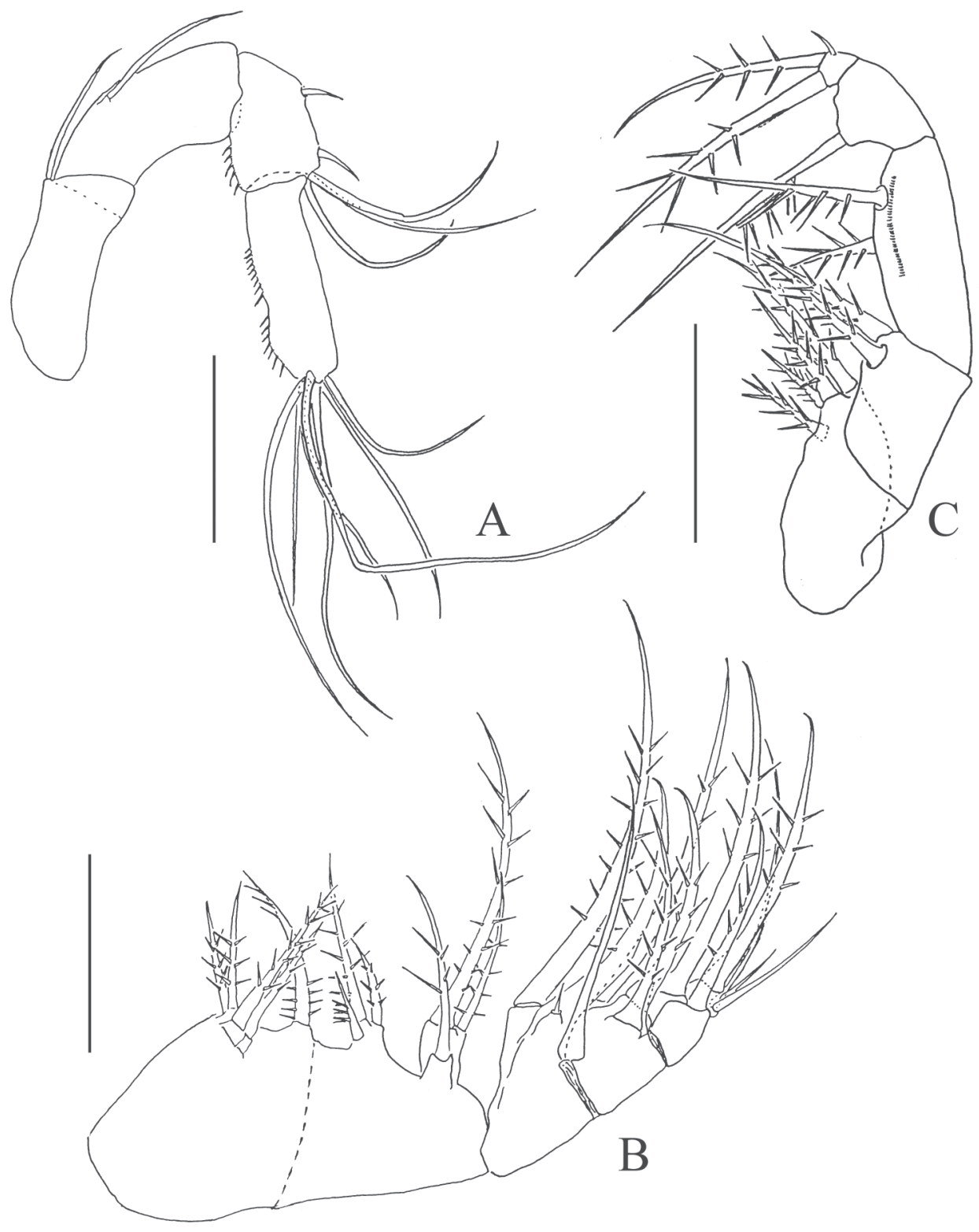

Fig. 4. Limnoithona tetraspina Zhang et Li, 1976. Female.

A - antenna; B - maxilla; C - maxilliped. Scale bars: A-C $-0.025 \mathrm{~mm}$.

Рис. 4. Limnoithona tetraspina Zhang et Li, 1976. Самка:

A — антенна; В — максилла; C - максиллипед. Масштаб: A-C — 0,025 мм.

on its endopod; 1 seta on the middle endopodal segment of swimming leg 4 , and no setae on the endopod modified with a flange; male cephalo- some without pores with cilia. However, a rounded projection between rostrum and labrum, a second, small seta on the exite of the maxillule, 

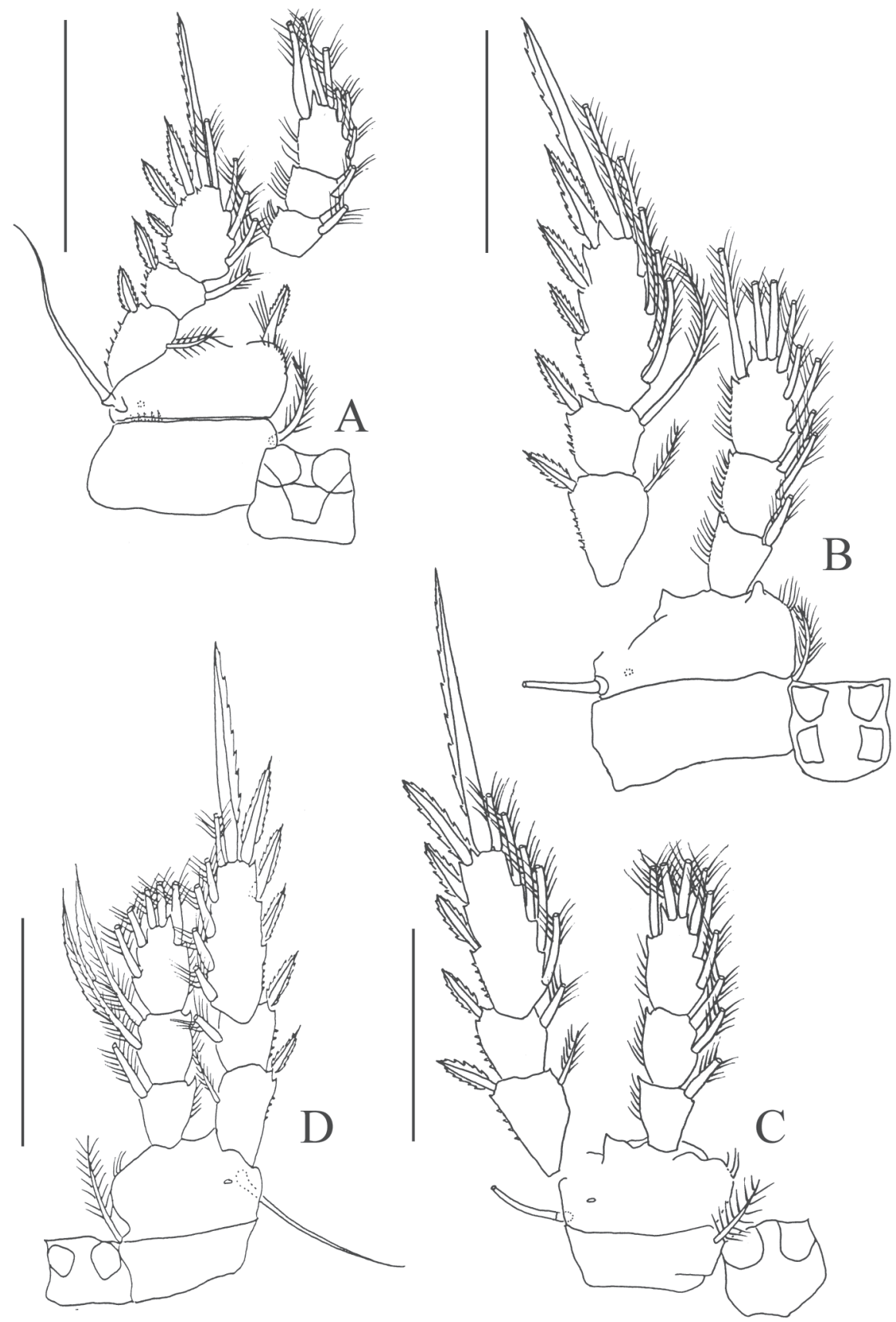

Fig. 5. Limnoithona tetraspina Zhang et Li, 1976. Female.

A - $\operatorname{leg} 1 ; \mathrm{B}-\operatorname{leg} 2 ; \mathrm{C}-\operatorname{leg} 3 ; \mathrm{D}-\operatorname{leg} 4$. Scale bars: A-D $-0.05 \mathrm{~mm}$.

Рис. 5. Limnoithona tetraspina Zhang et Li, 1976. Самка:.

A - 1-я нога; В - 2-я нога; $\mathrm{C}-3$-я нога; D -4 -я нога. Масштаб: A-D - 0,05 мм. 
1 brush-like seta on the exopod of the mandible and 1 brush-like seta on the maxillule were missed in the redescription of the species by Ferrari and Orsi (1984).

Limnoithona tetraspina differs from L. sinensis by having a rostrum more pronounced ventrally; 1 seta more on the proximal lobe of the basis and 1 seta more on the endopod of maxillule; middle endopodal segment of swimming legs 2-4 with 2 setae; proximal and distal seta of the middle endopodal segment of swimming leg 4 with a flange; exopod of leg 5 with a proximal lateral seta; male cephalosome ventrally with pores with cilia. We have chosen to retain these two species in Limnoithona, although differences between them are comparable in number and degree of transformation to differences among Paroithona, Dioithona, and Oithona within the Oithonidae.

\section{Distribution}

Limnoithona tetraspina, like its only congener $L$. sinensis, initially was described from the low salinity waters of the mouth of the Yangtze River in China. Subsequently both species were reported from the Sacramento/San Joaquin estuary, in California, USA. A synanthropic introduction, perhaps mediated by ship ballast water, would imply the Sacramento-San Joaquin animals were separated from those of the Yangtze for no more than 200 years, with the beginning of trans-Pacific shipping (Ferrari, Orsi, 1984). Ishida (2002) recently reported a female of Limnoithona sp. from a lower reaches of the Urauchi River in Iriomote Island, the Ryukyus, although these specimens may belong to Oithona dissimilis (26 March 2005 e-mail from Hiroshi Ueda to FDF).

\section{Discussion}

When the first cladistic studies of cyclopoid copepods were published (Ho, 1986; Ho, Thatcher, 1989), Oithonidae (consisting of species of Limnoithona, Oithona, Dioithona, and $\mathrm{Pa}$ roithona) was considered a monophyletic taxon based on the presence of a well-developed, claw-like seta rather than a claw-like attenuation on what was then considered the basis of the maxilla (this segment is now interpreted to be the proximal endopodal segment (Ferrari, Ivanenko, 2005)). Although a claw-like seta may be presumed to form in three oithonid genera (Oithona, Dioithona, and Paroithona), this is not the case for species of Limnoithona. In Limnoithona, a robust attenuation of the segment, often termed a claw, is present on this segment of the maxilla. Subsequent phylogenies for Cyclopoida proposed by Ho (1994) and Ho et al. (1998) recognized the presence of one seta in the epipodite of the maxillule as a synapomorphy of Oithonidae. This holds true for most species in the oithonid genera Oithona, Dioithona, and Paroithona, although the descriptions of some species do not indicate any seta. However, this state does not apply to Limnoithona, which shows two setae on the epipodite, a state shared with species of Psammocyclopinidae (see Martínez Arbizu, 2001a), Smirnovipina (see Martínez Arbizu, 1997a), and Notodeophyidae (see Dudley, 1966). Moreover, some species in cyclopoid families Cyclopettidae (see Martínez Arbizu, 2000a), Cyclopinidae (see Martínez Arbizu, 1997b; Elwers et al. 2001; Ivanenko, Defaye, 2004), Giselinidae (see Martínez Arbizu, 2000b), Hemicyclopinidae (see Martínez Arbizu, 2001b), and Speleoithonidae (see Rocha, Iliffe, 1991, 1993) also bear only one seta on this epipodite.

Presence of two setae on the distal enditic lobe of the basis of the maxillule of Limnoithona has not been observed in Oithona, Dioithona, and Paroithona (see Nishida, 1985) although it has been reported for Cyclopinidae (see Lotufo, 1994), Giselinidae, Pterinopsillidae (see Wilson, 1973) and Smirnovipina. Species of Oithona, Dioithona, and Paroitho$n a$ express a slight elongation of the proximal endite of the basis of the maxillule, so that its setae are distinctly separate from those of the distal endite. This state is not observed for either species of Limnoithona. An easily overlooked state of the exopod of the maxillule is a short, brush-like seta in the medial position. In addition to Limnoithona, this seta also is ob- 


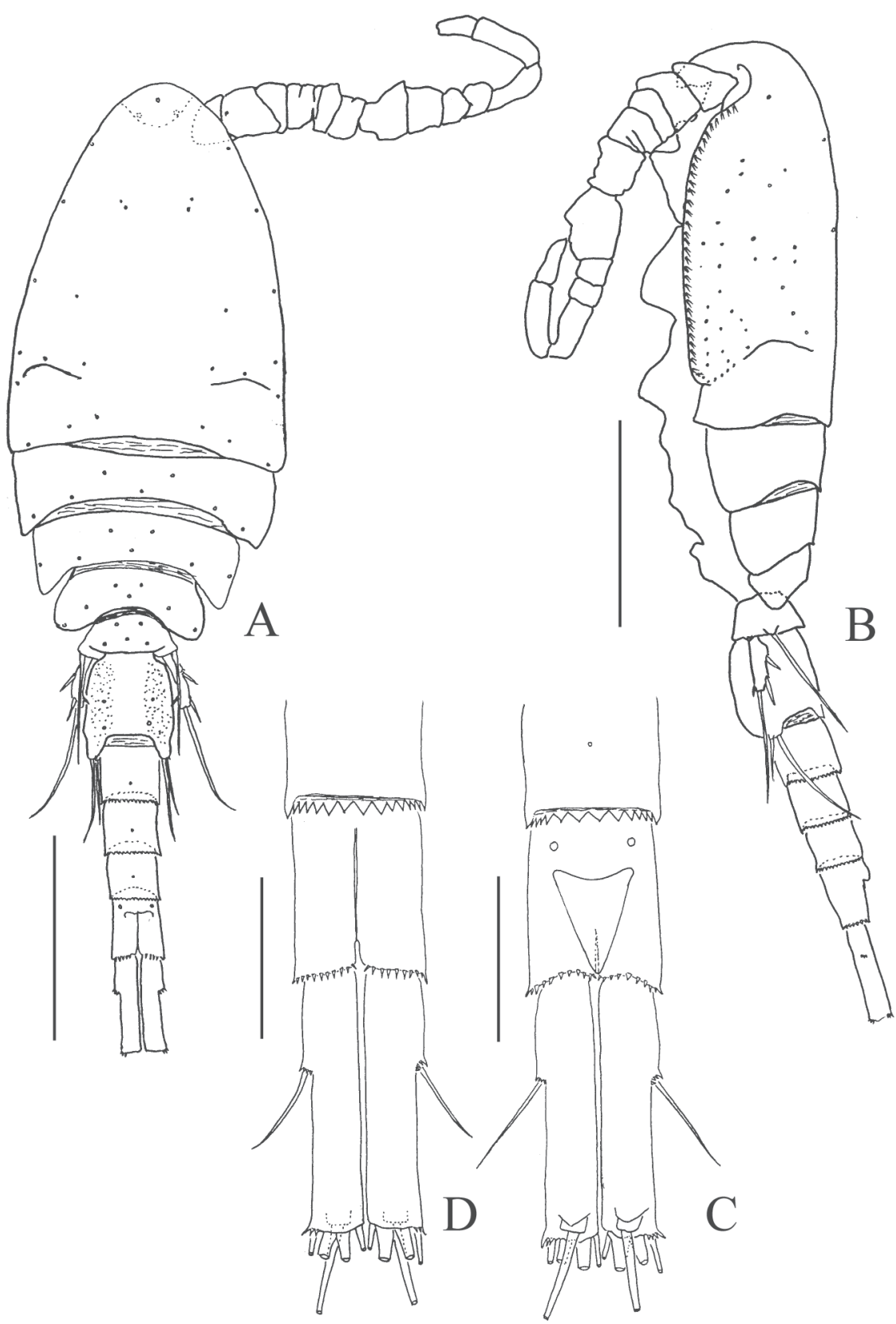

Fig. 6. Limnoithona tetraspina Zhang et Li, 1976. Male.

A - body, dorsal (left antennule not present); B — body, left lateral (oral appendages and swimming legs not present); $\mathrm{C}$ - anal segment and caudal ramus, dorsal; $\mathrm{D}$ - anal segment and caudal ramus, ventral. Scale bars: $\mathrm{A}-\mathrm{C}-0.10 \mathrm{~mm}$; $\mathrm{D}, \mathrm{E}-0.025 \mathrm{~mm}$.

Рис. 6. Limnoithona tetraspina Zhang et Li, 1976. Самец:

А - общий вид со спины (левая антеннула не показана); В - общий вид слева (околоротовые конечности и плавательные ноги не показаны); C - анальный сегмент и каудальная ветвь, вид со спины; D - анальный сегмент и каудальная ветвь, вид снизу. Масштаб: А-C - 0,10 мм; D, E - 0,025 мм. 


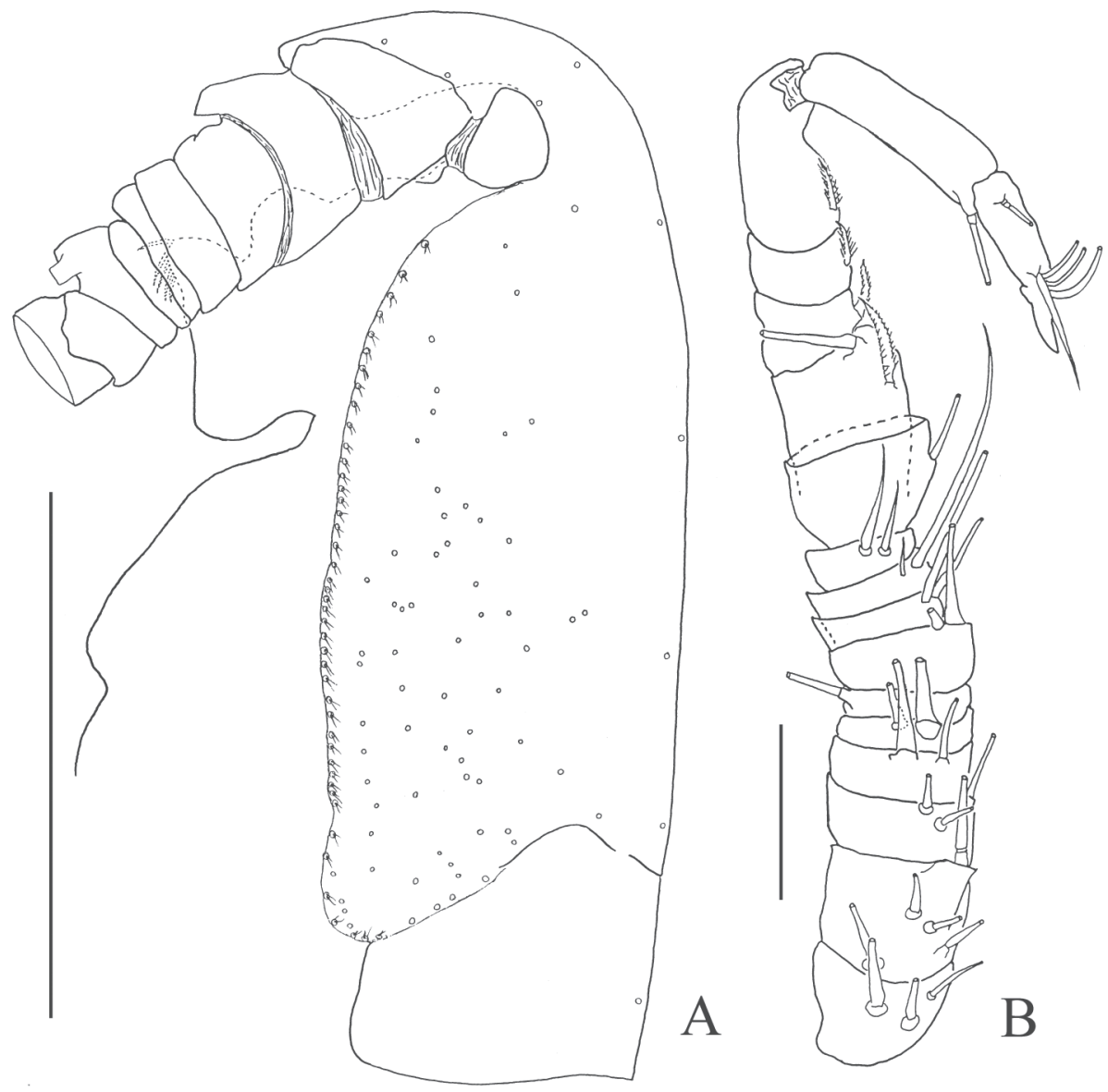

Fig. 7. Limnoithona tetraspina Zhang et Li, 1976. Male.

A - cephalothorax, lateral; B - antennula. Scale bars: A $-0.10 \mathrm{~mm}$; B $-0.025 \mathrm{~mm}$.

Fig. 7. Limnoithona tetraspina Zhang et Li, 1976. Самец:

А - цефалоторакс, вид сбоку; В - антеннула. Масштаб: А - 0,10 мм; В - 0,025 мм.

served on Oithona (unpublished observations), Dioithona (see Ferrari, Ambler, 1992), the hemicyclopinid genus Procyclopina (unpublished observations), and for the cyclopinid genera Cyclopina (see Gómez, Martínez Arbizu, 2004) and Heptnerina (see Ivanenko, Defaye, 2004). It has not been reported on the exopod of the maxillule of Paroithona or other cyclopoids.

The structure of the mandibular palp of the female of both species of Limnoithona, in which the proximal segment of the endopod articulates with the basis, differs from Oithona, Dioithona, and Paroithona. On females of the latter three genera, the arthrodial membrane separating the proximal segment of the endopod from the basis fails to form, although this arthrodial membrane is expressed in males of these three oithonid genera. Setal armament of the proximal endopodal segment of the mandible of the endopod of Limnoithona differs conspicuously from that of Oithona, Dioithona, and Paroithona. In the latter three genera, the proximal endopodal segment bears two setae, usually thick and ge- 
nerally ornamented with short, densely-packed setules in estuarine species, or with more sparsely-spaced setules in neritic and oceanic species (Nishida, 1985). One or both of these setae are thicker relative to the seta of the basipod. Limnoithona bears three setae on this segment, the largest number known for any cyclopoid and a state shared with species of Cyclopinidae and Notodelphyidae. The presence of one or two thick setae extending from the fused proximal endopodal segment out over the labrum of $\mathrm{Oi}$ thona, Dioithona or Paroithona is considered a complex synapomorphy uniting the true oithonids. An easily overlooked state of the exopod of the mandible is a short, brush-like seta in the terminal position of the distal segment; this seta has been observed on Limnoithona, Oithona (see Ferrari, 1981), Dioithona (see Ferrari, Ambler, 1992), the hemicyclopinid genus Procyclopina (unpublished observations), and on the cyclopinid genera Cyclopina (see Smirnov, 1935; Lotufo, 1994; Gómez, Martínez Arbizu, 2004) and Heptnerina (see Ivanenko, Defaye, 2004). A simple, unmodified seta is present in this position onParoitho$n a$ and other cyclopoids.

The proximal segment of the 2-segmented endopod of the maxilliped bears one seta on species of Limnoithona, as well as species of Cyclopettidae, some species of Speleoithona and many species of Cyclopidae. On species of the remaining genera of the Cyclopidae, as well as other species of Speleoithona, the three oithonid genera, and species of Psammocyclopinidae, Smirnovipina, Cyclopinidae, Giselinidae and Hemicyclopinidae, the endopod of the maxilliped consists of more than two segments or the proximal segment bears more than one seta. Developmental studies of selected species among this second group show that the endopod develops through the early copepodid stages by adding arthrodial membranes and setae so that the ramus is more than 2-segmented, or by adding only setae resulting in segment complexes with more than one seta (Ferrari, Ivanenko, 2001, 2005). Development of L. sinensis and many species of Cyclopidae shows that a 2-segmented endopod with only one seta results from a trun- cation of maxilliped development after the first copepodid stage (Ferrari, Ivanenko, 2001).

The proximal seta and the distal seta of the middle segment of the endopod of swimming leg 4 ofLimnoithona tetraspina is modified by the addition of a distal flange. Species of Dioithona and Oithona, with the exception of $O$. simplex, have the distal seta, or the proximal seta and the distal seta of this segment modified in this way. In addition, the proximal seta of the distal segment of both oithonid genera also is modified with a distal flange. On species of Oithona, these setae often are curved rather than straight, as they are in L. tetraspina and species of Dioithona. In the monotypic genus Smirnovipina, the proximal seta and the distal seta of the middle segment, and the proximal seta of the distal segment are similarly modified. Species of Speleoithonidae are variable. The proximal seta and the distal seta of the middle segment, and the proximal seta of the distal segment are modified on Speleoithona salvadorensis Rocha et Iliffe, 1991; the proximal seta and the distal seta of the middle segment, and the proximal seta plus the middle seta of the distal segment are modified on S. bermudenensis Rocha et Iliffe, 1993. Speleoithona elutherensis Rocha et Iliffe, 1991 has only one seta on the middle endopodal segment; it is modified with a flange, as is the proximal seta and one terminal seta of the distal segment. Similarly derived setae are absent fromLimnoithona sinensis, from species of Paroithona (see Nishida, 1986; Ferrari, Boettger, 1986) as well as all remaining cyclopoids.

Partial fusion dorsally between the cephalosome and the tergite of the first pedigerous somite was observed in males and females of both species of Limnoithona; a short, lateral extension of the posterior corner of the cephalosome also is present in both genders. A partial fusion and similar lateral extension has been reported for the female of Cyclopetta boetiusae Martínez Arbizu, 2000 but not for the female of the type species, $C$. difficilis. The pedigerous somite articulates completely with the cephalosome of both genders of Oithona, Paroithona, and Dioithona; Oithona males express a dis- 

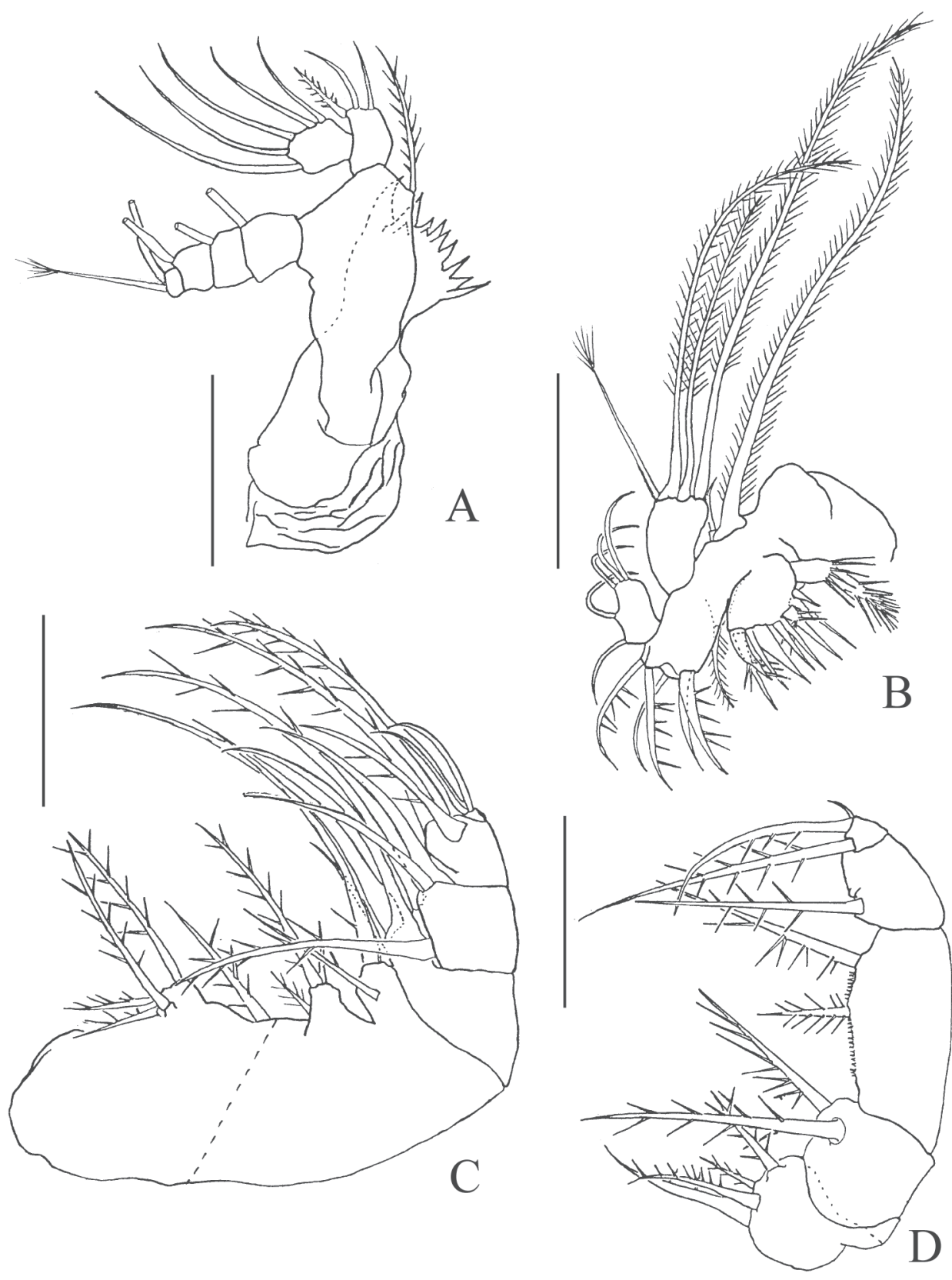

Fig. 8. Limnoithona tetraspina Zhang et Li, 1976. Male.

A - mandible; B - maxillule; C - maxilla; D - maxilliped. Scale bars: A-D - $0.025 \mathrm{~mm}$.

Pис. 8. Limnoithona tetraspina Zhang et Li, 1976. Самец:

A - мандибула; В — максиллула; C - максилла; D - максиллипед. Масштаб: A-D - 0,025 мм. 


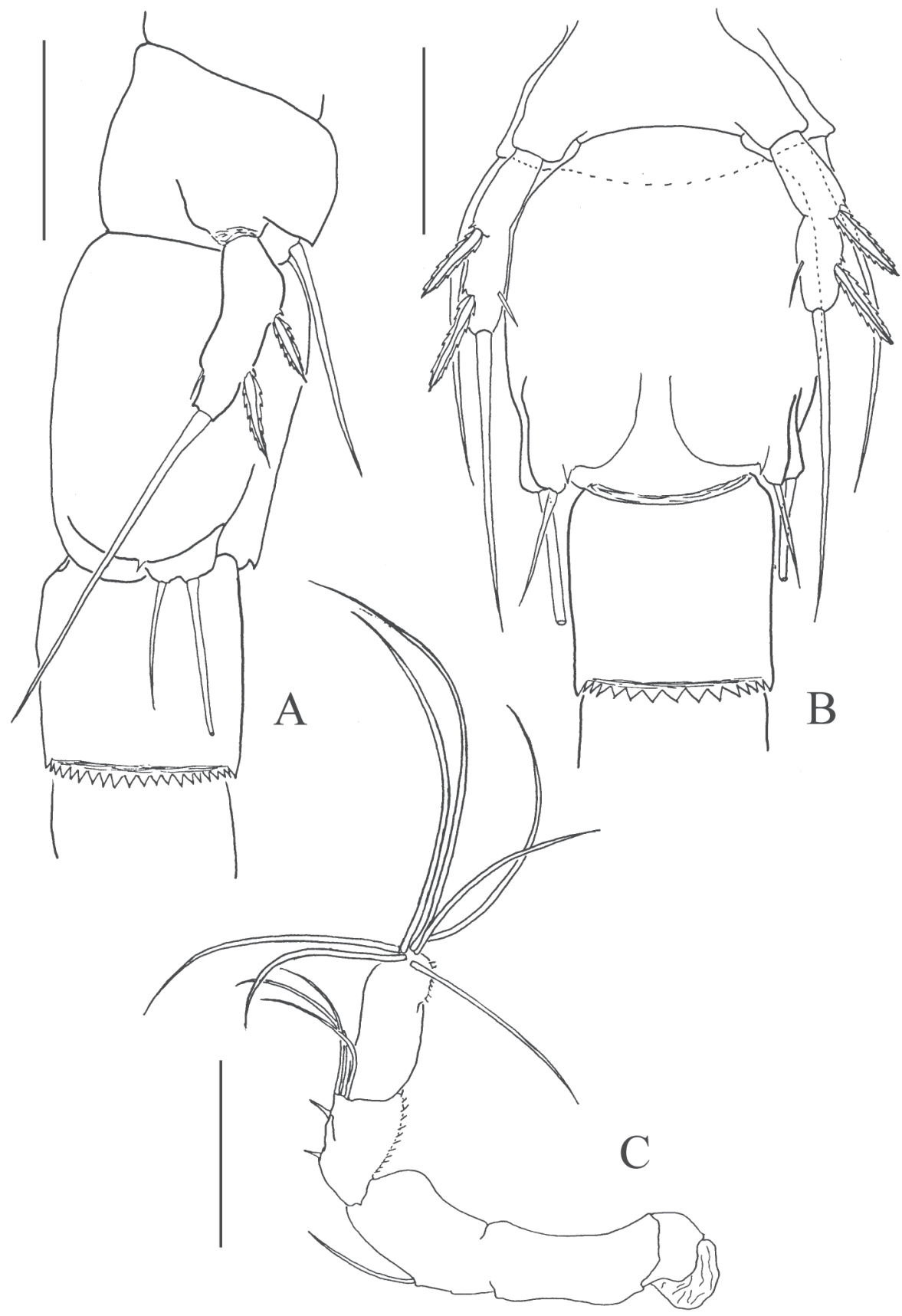

Fig. 9. Limnoithona tetraspina Zhang et Li, 1976. Male.

A - legs 5 and 6, left lateral; B - legs 5 and 6, ventral; C - antenna. Scale bars: A-C $-0.025 \mathrm{~mm}$.

Pис. 9. Limnoithona tetraspina Zhang et Li, 1976. Самец:

A - 5-я и 6-я нога, вид слева; В - 5-я и 6-я нога, вид снизу; С - антенна. Масштаб: А-C $-0,025$ мм. 
tinct lateral extension of the cephalosome (Ferrari, 1977; Ferrari, Bowman, 1980; Rocha, 1985), but males of Paroithona and Dioithona lack this extension.

Pores, each with a pair of cilia, located along the ventral margin of cephalosome and along the ventral and posterior margins of the lateral extensions of the cephalosome, appear unique to the males ofLimnoithona tetraspina; they are not shared with $L$. sinensis. Similar pores with cilia are known to form complex patterns on the lateral cephalosome of males of other cyclopoids. Males of most species of Oithona, with the exception of $O$. bjornbergae, bear a characteristic pore pattern on the ventrolateral face of the cephalosome and its lateral extension (Ferrari, 1977; Ferrari, Bowman, 1980; Rocha, 1985). A pair of cilia, composed of 50-60 microtubules, protrudes through each pore from a spherical cavity within the cephalosome (Nishida, 1986). The lateral extension of the cephalosome then appears to increase the surface area upon which pores open because there are no spherical cavities on the somite directly beneath the lateral extensions. This pattern of ciliated pores has been implicated in a precopulatory, mate-locating, swimming behavior of Oithona males (Uchima, 1985; Uchima, Murano, 1988). The diversity of pore patterns and the presence of pores on the lateral extensions suggests that pore spacing is important to this behavior of males of Oithona.

Pores with a pair of cilia on the lateral face of the cephalosome also are known for the planktonic male morph of the notodelphyid cyclopoid Pachypygus gibber, a parasite of tunicates (Hipeau-Jacquotte, 1978, 1984). Neither the female nor the sedentary male morph bears these pores, and neither the planktonic male morph nor the sedentary male morph has lateral extensions of the cephalosome (HipeauJacquotte, 1980, 1986). The ciliated pores are sensory and their structure is similar to that of males of Oithona. However, exocrine glands are associated with the ciliated pores of the planktonic males of $P$. gibber (see HipeauJacquotte, 1978). Pores of the planktonic male have been hypothesized to function in locating a female within its tunicate host, rather than the host itself (Hipeau-Jacquotte, 1986).

Males of other cyclopoids, like Limnoithona sinensis and species of Paroithona and Dioithona, lack pores with cilia. Among these species, mate location has been studied only for $D$. oculata. Males and females of this species copulate early in the morning in shafts of light which also provide a general cue for daytime swarm formation of the copepodids (Ambler et al., 1999). A complex swimming behavior for mate location utilizing a pattern of pores with cilia as hypothesized for Oithona males (Unchima, Morano, 1988) would appear to be redundant for males of $D$. oculata.

The armament of the exopod of P5 is difficult to compare. Limnoithona tetraspina has two lateral spines, one apical seta, and one medial seta; the proximal lateral spine is absent from L. sinensis. Species of Oithona, Dioitho$n a$, and Paroithona bear only an apical seta on the exopod of leg 5; presumably this seta is homologous to the apical seta of both species of Limnoithona. Species of Dioithona bear two setae on the exopod of leg 5 and these are hypothesized here to be the apical seta and the medial seta of both species of Limnoithona. Absence of both lateral setae of the exopod of leg 5 separates Oithona, Dioithona, and Paroithona from Limnoithona.

\section{Conclusions}

Because the states of many of the characters discussed above remain poorly studied among cyclopoids, the following conclusions may change as new observations become available. A rounded projection between the labrum and the rostrum of both genders appear to be a synapomorphy for the two species of Limnoithona. The two species of Limnoithona do not share with species ofOithona and Paroithona: an elongate mandibular basis; fusion of the proximal endopodal segment of the mandible of females to the basis; 2 setae of the fused proximal endopodal segment of the mandible extending ventrally over the labrum; 3 setae on the proximal endopodal complex of the maxil- 

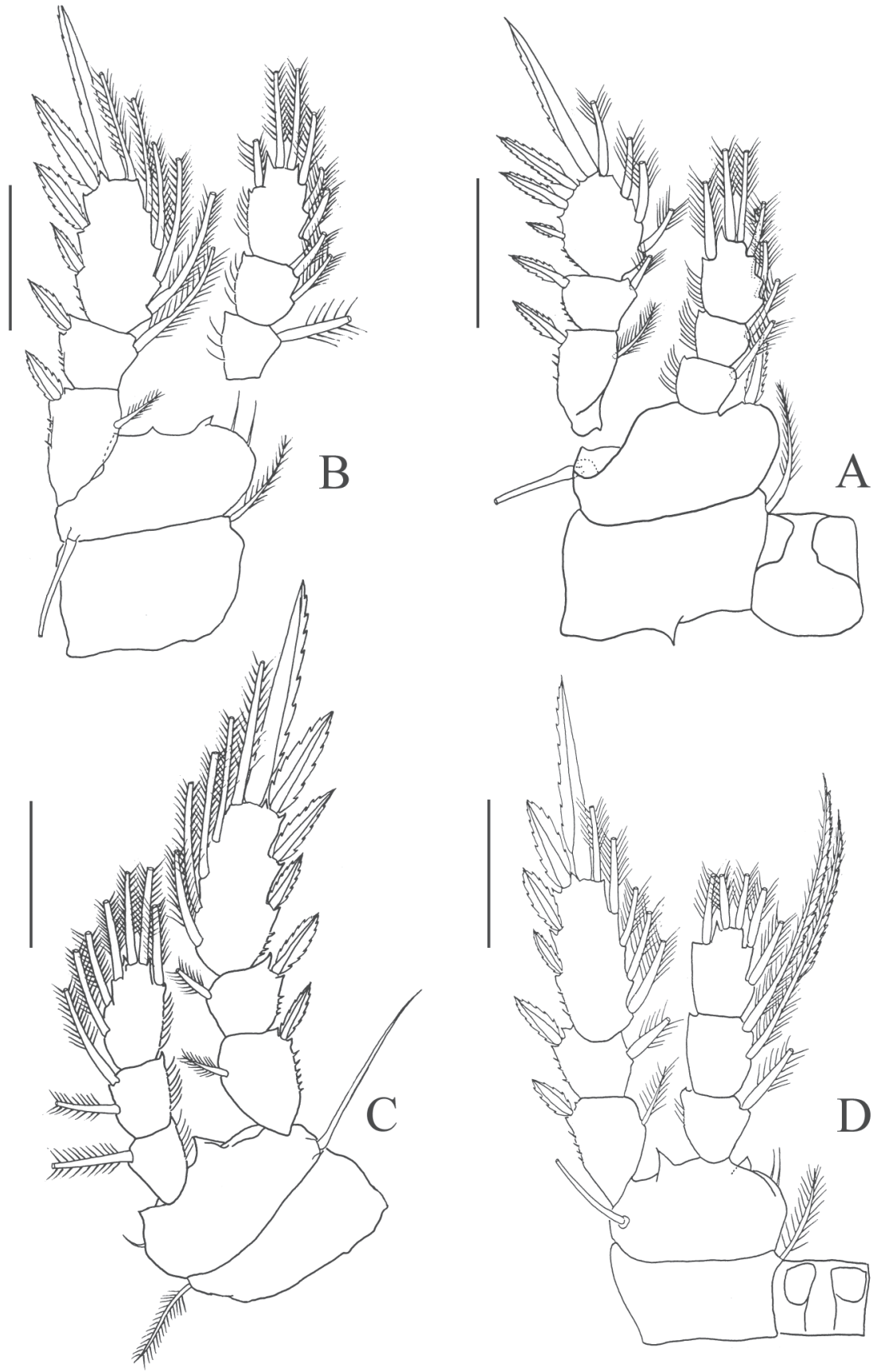

Fig. 10. Limnoithona tetraspina Zhang et Li, 1976. Male.

A - leg 1, B - leg 2; C - leg 3; D - leg 4. Scale bars: A-D - $0.025 \mathrm{~mm}$.

Рис. 10. Limnoithona tetraspina Zhang et Li, 1976. Самец:

A - 1-я нога, В - 2-я нога; $\mathrm{C}-3$-я нога; D - 4-я нога. Масштаб: $\mathrm{A}-\mathrm{D}-0,025$ мм. 
liped. These states appear to be synapomorphies for Oithonidae, and therefore both species of Limnoithona should be removed from Oithonidae.

Several derived states should be considered when placing Limnoithona within a larger lineage of cyclopoid families. A brush-like seta on the exopod of the mandible and a brush-like seta on the exopod of the maxillule is shared with Oithona, Dioithona and the cyclopinid genus Heptnerina; absence of these setae appears to be a secondary loss and an apomorphy of Paroithona. Presence of sensory pores, each with a pair of cilia, that originate on the cephalosome of males of L. tetraspina is shared with most species ofOithona andPachyptylus; these pores appear to have been lost secondarily from $L$. sinensis, as well as from all species ofDioithona and all species of Paroithona. Presence on the endopod of swimming leg 4 of one or more setae modified with a distal flange is shared among species of Oithona, Dioithona, Smirnovipina and Speleoithonidae, but the modification apparently is lost in L. sinensis, and species of Paroithona and other cyclopoids. A lateral extension of the female cephalosome and absence dorsally of the arthrodial membrane separating the cephalosome and pediger 1 are shared by females of both species Limnoithona and the female of Cyclopetta boetiusae Martínez Arbi$\mathrm{zu}, 2000 \mathrm{a}$. A lateral extension of the male cephalosome ofLimnoithona is shared with males of Oithona although the cephalosome and tergite of the first pedigerous somite are fused dorsally on males of Oithona. Presence of only one seta on the proximal endopodal segment of the maxilliped, which results from the truncated development of the ramus after first copepodid stage, appears to be shared with species of Cyclopettidae. However, this state also is derived convergently within the family Cyclopidae, because species in basal genera of the family bear more setae and segments (Ferrari, Ivanenko, 2001, 2005) . These states also appear to order species of Oithona, Dioithona and Paroithona, along with species of Limnoithona and Cyclopettidae within a larger cyclopoid lineage.
A close relationship between Oithonidae, including Limnoithona, and Cyclopettidae has been suggested previously by Martínez Arbizu (2000a) based on the lateral position of the copulatory pores, of leg 6 and of leg 5 , the loss of the inner coxal sclerite of leg 5 , and loss of the arthrodial membrane between the protopod of leg 5 and its somite so that the lateral basal seta appears to originate on the sixth somite. However, these states of Cyclopettidae may be convergent within the Oithonidae. A lateral extension of the female cephalosome and the dorsal fusion of the cephalosome and tergite of the first pedigerous somite in both genders eventually may prove to be a synapomorphy of the Cyclopettidae including Limnoithona, but the state of these characters is not known for most species presently included within the Cyclopettidae (Martínez Arbizu, 2000a). The modified, brush-like seta on the exopod of the mandible and on the exopod of the maxillule, and the modified flage setae on swimming leg 4 of the Oithonidae including one species of Limnoitho$n a$ have not been reported for any species of Cyclopettidae. Until a systematic evaluation of all of these characters is undertaken, assigning the two species of Limnoithona to a known family of the Cyclopoida or to propose a new family for them would not be useful. However, the two species of Limnoithona are closely related to species of Cyclopettidae as the following analysis suggests.

There appears to be a large monophyletic lineage of basal cyclopoids which can be diagnosed with: a brush-like seta on exopod of mandible; a brush-like seta on exopod of maxilla 1; one or more medial setae on the endopod of swimming leg 4 modified with a flange; pores on the male cephalothorax. In addition, the endopod of the maxilliped of these basal cyclopoids develops during the copepodid phase resulting in a number of different and important configurations of this ramus (Ferrari, Ivanenko, 2001). The above states may have existed for the ancestral cyclopoid.

Within this large monophyletic lineage is a restricted lineage diagnosed by: leg 5 in lateral position; loss of the inner coxal sclerite of leg 5; 
protopod (basis) of leg 5 fused to sixth somite so that the lateral basal seta appears to originate on the sixth somite; copulatory pore and leg 6 in lateral position on seventh thoracic somite. This restricted lineage may include species of the four genera proposed for Cyclopettidae (Martínez Arbizu, 2000), Cyclopetta, Paracyclopetta, Arctocyclopina and Paracyclopina, the two species of Limnoithona plus Cyclopina intermedia Sewell, 1924 and Cyclopina longifurca Sewell, 1924, and the species of Oithonidae. Unfortunately not all of these characters have been observed for all of the species, so a number of the states are unknown. No taxonomic name is proposed for this restricted lineage.

Within the restricted lineage, the Oithonidae can be diagnosed by: an elongate mandibular basis whose two setae extend ventral to the labrum; a proximal complex of three endopodal segments on the maxilliped which is the result of the continued development of this endopod during the copepodid phase. The continued development is not a synamporphy because it is shared with many basal cyclopoids; the synapomorphy is the proximal complex of three endopodal segments. The endopod of the maxilliped of Cyclopina intermedia and Cyclopina longifurca possess more than one seta suggesting a segment complex, but the conformation of this ramus does not resemble that of the Oithonidae nor is their mandibular basis elongate. The position of Cyclopina longifurca and $C y$ clopina intermedia within the restricted lineage is uncertain.

Also within the restricted lineage, the species of Limnoithona, Cyclopetta, Paracyclopetta, Arctocyclopina and Paracyclopina share a maxilliped endopod whose proximal segment is not a segment complex; it is a single segment bearing one medial seta. This state results from an endopod whose development is truncated after the first copepodid stage, and the state is an apomorphy for the species of these five genera. However, it cannot be proposed unabiguously as a synapomorphy to diagnose the Cyclopettidae because the state has evolved at least one other time, within the Cyclopidae. So a hypothesis that it may also have evolved more than once among Limnoithona, Cyclopetta, Paracyclopetta, Arctocyclopina and Paracyclopina must be considered. Both genders of some species of Limnoithona, Cyclopetta, Paracyclopetta, Arctocyclopina and Paracyclopina also share a lateral extension of the female cephalosome and dorsal fusion of the cephalosome and tergite of the first pedigerous somite. If these two states plus the state of the proximal endopodal segment of the maxilliped are proposed for the ground pattern of the Cyclopettidae then Limnoithona and Cyclopetta would be placed in the family. The status ofParacyclopetta, Arctocyclopina and Paracyclopina would remain ambiguous due to lack of observations.

\section{Acknowledgements}

We are grateful to Fundação de Amparo à Pesquisa do Estado de São Paulo (FAPESP) for providing funding during the doctorate program that made possible the elaboration of this paper; to the Universidade de São Paulo for physical, technical and academic support; to James Orsi, from the California Department of Fish and Game for providing theLimnoithona tetraspina specimens examined.

\section{References}

Ambler J.W., Ferrari F.D., Fornshell J.A., Buskey E.J. 1999. Diel cycles of molting, mating, egg production and hatching in the swarm forming cyclopoid copepod Dioithona oculata // Plankton Biology and Ecology. Vol.46. P.120-127.

Boxshall G.A. 1985. The comparative anatomy of two copepods, a predatory calanoid and a particle-feeding mormonilloid // Philosophical Transactions of the Royal Society of London Ser. B Biological Sciences. Vol.311. P.303-377.

Burckhardt G. 1913. Wissenschaftliche Ergebnisse eine Reise um die Erde von M. Pernud und C. Schröeder. III. Zooplankton aus ost-und südasiatischen Binnengewässern // Zoologische Jahrbücher, Abteilung für Systematik, Ökologie und Geographie der Tiere. Bd.34. S.341-472.

Dudley P.L. 1966. Development and systematics of some Pacific marine symbiotic copepods. A study of the biology of the Notodelphyidae, associates of ascidians // University of Washington Publictions in Biology. Vol.21. P.1-282. 
Elwers K., Martinez Arbizu P., Fiers F. 2001. The genus Pseudocyclopina Lang in Antarctic waters: Redescription of the type-species, P. belgicae (Giesbrecht, 1902) and the description of four new species: (Copepoda: Cyclopinidae) // Ophelia. Vol.54. P.143-165.

Ferrari F.D. 1977. A redescription of Oithona dissimilis Lindberg, 1940 with a comparison to Oithona hebes Giesbrecht, 1891 (Crustacea: Copepoda: Cyclopoida) // Proceedings of the Biological Society of Washington. Vol.90. P.400-411.

Ferrari F.D. 1981. Oithona wellershausi n. sp. and $O$. spinulosa Lindberg, 1950 (Copepoda: Cyclopoida: Oithonidae) from the mouth of the Pearl River China // Proceedings of the Biological Society of Washington. Vol.94. P.1244-1257.

Ferrari F.D. 1995. Six copepodid stages of Ridgewayia klausruetzleri, a new species of calanoid copepod (Ridgewayiidae) from the barrier reef in Belize, with comments on appendage development // Proceedings of the Biological Society of Washington. Vol.108. P.180-200.

Ferrari F.D., Ambler J.W. 1992. Nauplii and copepodids of the cyclopoid copepod Dioithona oculata (Oithonidae) from a mangrove cay in Belize // Proceedings of the Biological Society of Washington. Vol.105. P.275-298.

Ferrari F.D., Boettger R. 1986. Sexual dimorphism and a sex-limited polymorphism of Paroithona pacifica (Cyclopoida: Oithonidae) from the Red Sea // Proceedings of the Biological Society of Washington. Vol.99. P.274-285.

Ferrari F.D., Bowman T.E. 1980. Pelagic copepods of the family Oithonidae (Cyclopoida) from the east coasts of Central and South America // Smithsonian Contributions to Zoology. No.312. 27 p.

Ferrari F.D., Ivanenko V.N. 2001. Interpreting segment homologies of the maxilliped of cyclopoid copepods by comparing stage-specific changes during developmen // Organisms Diversity Evolution. Vol.1. P.113-131.

Ferrari F.D., Ivanenko V.N. 2005. Copepodid stages of Euryte longicauda (Cyclopoida, Cyclopidae, Euryteinae) from the White Sea associated with the bryozoan Flustra foliacea // Journal of Crustacean Biology. Vol.25. P.353-374.

Ferrari F.D., Orsi J. 1984. Oithona davisae, new species, and Limnoithona sinensis (Burckhardt, 1912) (Copepoda: Oithonidae) from the Sacramento-San Joaquin Estuary, California // Journal of Crustacean Biology. Vol.4. P.106-126.

Gómez S., Martínez Arbizu P. 2004. First record of the genus Cyclopina (Copepoda: Cyclopoida), and fully illustrated redescription of Cyclopina caissara from northwestern Mexico // Anales Instituto de Biollogía, Universidad Nacional Autónoma de México, Ser. Zool. Vol.75. P.121-134.

Hipeau-Jacquotte R. 1978. Existence de deux formes sexuelles mâles chez le Copépode ascidicole Notodelphyidae Pachypygus gibber(Thorell, 1859)//Comptes Rendus de l'Académie des Sciences, Paris. T.287. P.253-256.
Hipeau-Jacquotte R. 1980. Le développement atypique du Copépode ascidicole Notodelphyidae Pachypygus gibber (Thorell, 1859) // Archives de Zoologie Expérimentale et Générale. Vol.121. P.29-47.

Hipeau-Jacquotte R. 1984. A new concept in the evolution of the Copepoda: Pachypygus gibber (Notodelphyidae), a species with two breeding males // Crustaceana, Supplement. Vol.7. P.60-67.

Hipeau-Jacquotte R. 1986 A new cephalic type of presumed sense organ with naked dendrite ends in the atypical male of the parasitic copepod Pachypygus gibber (Crustacea) // Cell and Tissue Research. Vol.245. P.29-35.

Ho J.-s. 1986. Phylogeny of Cyclopoida // Syllogeus. Vol.58. P.177-183.

Ho J.-s. 1994. Origin and evolution of the parasitic cyclopoid copepods // International Journal of Parasitology. Vol.24. P.1293-1300.

Ho J.-s., Thatcher V.E. 1989. A new family of cyclopoid copepods (Ozmanidae) parasitic in the hemocoel of a snail from the Brazilian Amazon // Journal of Natural History. Vol.23. P.903-911.

Ho J.-s., Conradi M., López-González P.J. 1998. A new family of cyclopoid copepods (Fratiidae) symbiotic in the ascidian (Clavelina dellavallei) from Cádiz, Spain // Journal of Zoology. Vol.246. P.39-48.

Ishida T. 2002. Aspect on the planktonic copepods of inland waters // Biology of Inland Waters. Vol.17. P.1-7 [in Japanese].

Ivanenko V.N., Defaye D. 2004. A new genus and species of deep-sea cyclopoids (Crustacea, Copepoda, Cyclopinidae) from the Mid-Atlantic Ridge (Azores Triple Junction, Lucky Strike) // Zoosystema. Vol.26. P.49-64.

Kiefer F. 1928. Beitrage zue Copepodenkunde (VII) // Zoologischer Anzeiger. Bd.75. S.216-223.

Lotufo G.R. 1994. Cyclopina (Copepoda, Cyclopoida) from Brazilian sandy beaches // Zoologica Scripta. Vol.23. P.147-159.

Martínez Arbizu P. 1997a. A new genus of cyclopinid copepods (Crustacea), with a redescription of Smirnovipina barentsianacomb. nov. (Smirnov,1931) // Sarsia. Vol.82. P.313-323.

Martínez Arbizu P. 1997b. Cyclopicina sirenkoi n. sp. from deep water in the Laptev Sea (Arctic Ocean), with comments on the phylogenetic relationships of copepod orders (Crustacea: Copepoda: Cyclopoida: Cyclopinidae) // Senckenbergiana biologica. Bd.77. S.89-99.

Martínez Arbizu P. 2000a. A new species of Cyclopetta from the Laptev Sea (Arctic Ocean), with the recognition of Cylopettidae fam. nov., a new monophylum of the free-living Cyclopoida (Copepoda) // Bulletin van het Koninklije Belgisch vor Natuurwetenschappen. Vol.70. P.91-101.

Martínez Arbizu P. 2000b. Giselinidae fam. n., a new monophyletic group of cyclopoid copepods (Copepo$\mathrm{da}$, Crustacea) from the Atlantic deep sea // Helgoland Marine Research. Vol.54. P.190-212.

Martínez Arbizu P. 2001a. Psammocyclopinidae fam. n., a new monophyletic group of marine Cyclopoida (Cope- 
poda, Crustacea), with the description of Psammocyclopina georgei sp. n. from the Magellan Region // Revista Brasileira de Zoologica. Vol.18. P.1325-1339.

Martínez Arbizu P. 2001b. Hemicyclopinidae n. fam., a new monophyletic group of marine cyclopinid Cyclopoida, with description of one new genus and two new species. (Crustacea, Copepoda, Cyclopoida) // Senckenbergiana biologica. Bd.81. S.37-54.

Nishida S. 1985. Taxonomy and distribution of the family Oithonidae (Copepoda, Cyclopoida) in the Pacific and Indian Oceans // Bulletin of the Ocean Research Institute, University of Tokyo. Vol.20. P.1-167.

Nishida S. 1986. Structure and function of the cephalosome-flap organ in the family Oithonidae (Copepoda, Cyclopoida)// Syllogeus. Vol.58. P.385-391.

Rocha C.E.F. 1985. Freshwater copepods of the genus Oithona Baird, 1843 from the Amazonian Region (Brazil) // Revue d'Hydrobiologie Tropicale. T.18. P.213-220.

Rocha C.E.F., Iliffe T.M. 1991. Speleoithonidae, a new family of Copepoda (Cyclopoida) from anchialine caves on the Bahama Islands // Sarsia. Vol.76. P.167-175.

Rocha C.E.F., Iliffe T.M. 1993. New cyclopoids (Copepoda) from anchialine caves in Bermuda // Sarsia. Vol.78. P.43-56.

Sewell, R. B. S. 1924. Crustacea Copepoda: Fauna of Chilka Lake // Memoirs of the Indian Museum. Calcutta. Vol.5. P.771-851.

Smirnov S.S. 1935. Zur Systematik der Copepoden-Familie Cyclopinidae G.O. Sars Zoologischer Anzeiger. Bd.109. S.203-210.

Uchima M. 1985. Copulation in the marine copepod Oithona davisae Ferrari \& Orsi. I. Mate discrimination // Bulletin of the Plankton Society of Japan. Vol.32. P.23-30.

Uchima M., Murano M. 1988. Mating behavior of the marine copopod Oithona davisae // Marine Biology. Vol.99. P.39-45.

Wilson M.S. 1973. Two new species of the cyclopoid copepod genus Pterinopsyllus from the Gulf of Mexico // Bulletin of Marine Science. Vol.23. P.510-520. 